\title{
Bis(spirolactam) 1,3-Double-Armed Calix[4]arene Compounds and their Application as Extractants for the Determination of Heavy
}

\section{Metal lons}

\author{
Fintan Kelleher \\ Technological University Dublin, fintan.kelleher@tudublin.ie \\ Mary Deasy \\ Technological University Dublin, mary.deasy@tudublin.ie \\ James Ward \\ Technological University Dublin, james.ward@tudublin.ie
}

See next page for additional authors

Follow this and additional works at: https://arrow.tudublin.ie/ittsciart

Part of the Analytical Chemistry Commons, Organic Chemistry Commons, and the Other Chemistry Commons

\section{Recommended Citation}

Kelleher, F. et al. (2015) Bis(spirolactam) 1,3-double-armed calix[4]arene compounds and their application as extractants for the determination of heavy metal ions, Journal of Inclusion Phenomena and Macrocyclic ChemistryDec.2015, Vol. 83, Iss. 3, pp 377-386.

This Article is brought to you for free and open access by the School of Science and Computing at ARROW@TU Dublin. It has been accepted for inclusion in Articles by an authorized administrator of ARROW@TU Dublin. For more information, please contact arrow.admin@tudublin.ie, aisling.coyne@tudublin.ie, gerard.connolly@tudublin.ie. Funder: Irish Government

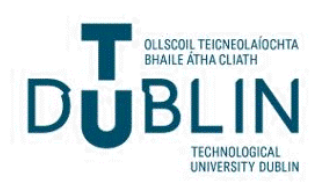




\section{Authors}

Fintan Kelleher, Mary Deasy, James Ward, Li Li, and Fiona Regan

This article is available at ARROW@TU Dublin: https://arrow.tudublin.ie/ittsciart/35 
Bis(spirolactam) 1,3-double-armed calix[4]arene compounds and their application as extractants for the determination of heavy metal ions

James Ward ${ }^{\mathrm{a}}, \mathrm{Li} \mathrm{Li}^{\mathrm{b}}$, Fiona Regan ${ }^{\mathrm{b}}$, Mary Deasy ${ }^{\mathrm{a}}$ and Fintan Kelleher*a

${ }^{a}$ Molecular Design \& Synthesis Group, Centre of Applied Science for Health, Institute of Technology

Tallaght, Dublin 24, Ireland.

${ }^{b}$ Marine and Environmental Sensing Technology Hub, School of Chemical Sciences, Dublin City University,

Glasnevin, Dublin 9, Ireland.

Corresponding Author: $\quad$ Dr. Fintan Kelleher

Address:

Department of Science,

Institute of Technology Tallaght,

Tallaght,

Dublin 24,

Ireland.

Phone Number: (+353 1) 4042869

Fax Number: $\quad$ (+353 1) 4042700

e-mail address: $\quad$ fintan.kelleher@ittdublin.ie 
Graphical abstract:

Bis(spirolactam) 1,3-double-armed calix[4]arene compounds and their application as extractants for the determination of heavy metal ions

James Ward, Li Li, Fiona Regan, Mary Deasy and Fintan Kelleher*

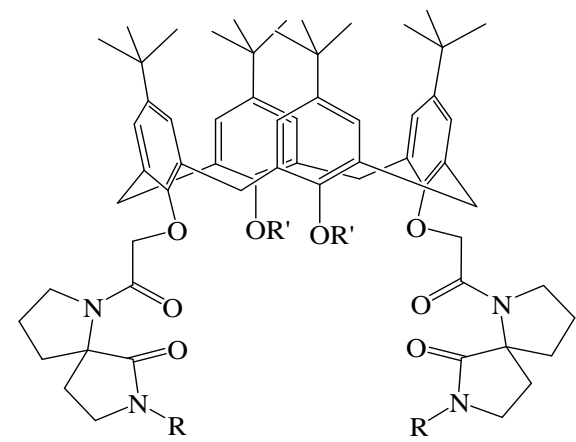

$\mathrm{R}=$ Benzyl, allyl, $-\mathrm{CH}_{2} \mathrm{COOCH}_{3}$ $\mathrm{R}^{\prime}=\mathrm{H}, \mathrm{CH}_{3}$ 
Bis(spirolactam) 1,3-double-armed calix[4]arene compounds and their application as extractants for the determination of heavy metal ions

James Ward, ${ }^{\mathrm{a}}$ Li Li, ${ }^{\mathrm{b}}$ Fiona Regan, ${ }^{\mathrm{b}}$ Mary Deasy ${ }^{\mathrm{a}}$ and Fintan Kelleher*a

\author{
${ }^{a}$ Molecular Design \& Synthesis Group, Centre of Applied Science for Health, Institute of Technology \\ Tallaght, Dublin 24, Ireland. \\ ${ }^{b}$ Marine and Environmental Sensing Technology Hub, School of Chemical Sciences, Dublin City University, \\ Glasnevin, Dublin 9, Ireland.
}

\begin{abstract}
A number of double-armed calix[4]arene compounds, with proline-derived spirolactam ligating groups on the lower rim, have been synthesised and investigated as extractants of toxic heavy metal ions from aqueous solution. Pedersen's extraction technique was employed to determine the capability of these new 1,3-distal derived calix[4]arene spiroalactams to extract selected heavy metal ions (e.g. $\mathrm{Pb}^{2+}, \mathrm{Cd}^{2+}, \mathrm{Zn}^{2+}, \mathrm{Cu}^{2+}, \mathrm{Ni}^{2+}$, $\mathrm{Co}^{2+}$ ) from an aqueous phase into an organic phase. The percentage extraction was calculated using UV-vis spectroscopy. All of the compounds synthesised demonstrated good selectivity for the heavy metals selected over the alkali metal and alkaline earth metal ions, in particular for $\mathrm{Pb}^{2+}$. The level of selectivity observed was dependent on the $N$-substituent of the spirolactam moiety attached to alternate phenolic oxygens of the narrow calix[4]arene rim. Interestingly, higher sensitivity and lower selectivity was found when the two remaining - $\mathrm{OH}$ groups were replaced by $-\mathrm{OCH}_{3}$ groups.
\end{abstract}

Keywords: Spirocyclic double-armed calix[4]arenes; spirolactam; heavy metal ion determination; $\mathrm{Pb}^{2+}$ determination; optical chemical sensors; ionophore.

\title{
1. Introduction
}

Selective monitoring of hazardous heavy metal and transition metal ions and their determination at low concentrations is a longstanding goal of many research and commercial groups, not least because of the need for high quality drinking water and the necessity for ultrapure water for injectable grade drug formulations hitting the market $[1,2]$. The presence of heavy metal ions such as $\mathrm{Cd}^{2+}, \mathrm{Pb}^{2+}$ and $\mathrm{Hg}^{2+}$ in water is not 
desirable, since they are not degradable and produce toxic effects at very low concentrations. Hence, the development of systems that can scavenge these metals at trace levels is vital. This can be achieved using macrocyclic scaffolds with chemical functionalities capable of trapping ionic species and removing them from aqueous media.

Calix[4]arenes are an important class of macrocyclic compounds which have been used extensively in supramolecular chemistry for molecular recognition [3-6]. They were first prepared by Baeyer in 1872, as by-products in the synthesis of baeklite [7]. Their synthesis was further improved by Zinke and Ziegler in $1944[8,9]$, and then early conformational studies were published in 1955 by Cornforth [10]. Since Gutsche first published the synthesis of calix[4]arene-based macrocycles [11], the investigation of the complexation properties of these compounds has been of intense interest for a wide variety of ionic species and small organic guest molecules, through the formation of host-guest or supramolecular complexes. This area is subject to regular in-depth reviews [3-6].

While the study of calixarenes with metal ions has attracted much attention, they have been less studied for binding to transition metal ions. Much of the current research into calixarenes focuses on the smallest and most rigid of the family, namely the calix[4]arenes, since the larger cavity-containing analogues are more flexible and therefore not always suited to strong binding with guest species, and are also generally less selective. Many calix[4]arene compounds have been synthesised over the last 40 years, with a variety of ligating groups to fine-tune binding to an array of ionic and neutral guests in solution and in the solid state [3-6]. Some of the functionalities attached to the calixarene scaffold are large and while they can facilitate binding can crowd the cavity and decrease the binding strength. In order to overcome this potential issue chemists have devised calix[4]arenes where only two of the phenolic OH groups possess ligating groups. These are referred to as 1,3-distal derivatised calix[4]arenes. In our previous work, we have synthesised such 1,3-distal derivatives which have been used in nanostructures capable of selectively sensing $\mathrm{Li}^{+}$and $\mathrm{Fe}^{3+}$ in aqueous solution [12]. Among the macrocyclic complexing agents for metal ions in general, distal 1,3substituted calix[4]arene-based ionophores currently occupy an important position [4].

Most early chemical sensors were based on small molecules, with suitable ligating groups capable of binding to the guest species, being detected and measured. However, these host systems are flexible, and they are not selective for one particular guest species in particular. By constraining the ligating groups in a ring system or 
within a larger macromolecular structure then conformational freedom should be reduced and the ligating groups should then bind more selectively to the guest molecule. If the macromolecule has a set 3-D geometry and/or has a cavity (like the calix[n]arenes) then this should pre-organise the ligating groups within the host compound even more for selective binding to the guest. The calixarene family has a rigid backbone comprising aromatic rings linked by tight methylene bridges, and therefore have the required architecture for entrapping small molecules and ions, and this has been well documented in the literature.

Another way to constrain the flexibility of small molecules is by incorporating a spirocyclic fusion into the molecule $[13,14]$. This gives a defined conformation with directionality to any ligating groups within the spirocyclic moiety. Spirocycles have been used to constrain the conformation of flexible molecules, in particular peptides, leading to an improvement in their chemical and biological properties [15]. They are composed of two or more ring hydrocarbons fused together by a quaternary carbon, and often have $\mathrm{N}$ or $\mathrm{O}$ atoms as part of the ring. These heteroatoms are commonly included compounds designed to act as synthetic hosts or ionophores, and are often linked to carbonyl groups to provide more binding sites within a host. This platform provides a highly-organised and rigid unit for the incorporation of amine and amide groups that have potential to bind specifically to small molecules or guests, a key feature of any chemical sensor. This is the first time macrocyclic cage-like compounds incorporating spirocyclic functionalities have been prepared for potential sensor application; where the calixarene provides a relatively inflexible cavity large enough to accommodate metal ions, and the spirocyclic antenna provide additional directionality to provide improved interaction with the guest metal ions.

Pederson's solvent extraction method, by using picrate salts of metal ions, is a useful method for studying the binding ability of macrocyclic molecules with metal ions [16]. Herein, we report the synthesis of a series of bis(spirolactam) 1,3-double-armed calix[4]arene receptors, on the lower rim and their binding properties with heavy-metal and transition-metal ions.

\section{Results and Discussion}

\subsection{Synthesis}

There are many literature reports of distal 1,3-bis(amido)-linked calix[4]arenes with a variety of ligating groups for binding to neutral, anionic and cationic guests [3-6]. In the vast majority of these cases the ligating groups have a large degree of conformational freedom. An underlying theme of our research for many years has been on the introduction of conformational constraint into flexible structures, in order to improve their 
binding properties to, for example, guest molecules. One method employed is the introduction of spirofused rings with defined conformational preferences due to the constraints imposed by their structure. We have reported previously on the synthesis, characterisation and binding properties of a number of proline-derived spirolactams and diamines [17-19]. The spirolactams were synthesised in good yields starting from L-proline (Figure 1). It was possible to easily vary the lactam ring $\mathrm{N}$-substituent to give a number of spirolactams which could be subsequently derivatised on the pyrrolidine nitrogen atom. It was thought that conjugation of the spirolactam moiety in a 1,3-distal manner to a calix[4]arene backbone, via a linker, would give compounds with a varied cavity size, capable of binding metal ions. Moreover, it might also be possible to tune the cavity size by the choice of the lactam ring $\mathrm{N}$-substituent, in order to give selective binding to target metal ions, such as heavy metal ions. The N-substituents initially chosen contained an ester group with potential for binding through the oxygen atoms, as well as two with potential for alkene- or arene-cation binding (Figure 1).

\section{Figure 1}

Literature syntheses of amide linked calix[4]arenes have mainly used three different methods to create the amide linker [3-6]. Firstly, aminolysis of an ester with an amine gave good yields of the amides, but this method is restricted to the use of primary amines. Secondly, coupling of amines to a carboxylic acid moiety using a variety of "peptide coupling" methods gave the amides in good yields, but again the vast majority of examples used primary amines or primary amino acids. The third method is the direct reaction of an amine with an acid chloride. McKervey reported this method for reactions involving secondary amines [20]. Since the spirolactams being used were secondary amines, and also highly sterically hindered, it was felt that this method was likely to give the best chance of success.

The first set of target spirolactam-calixarenes were synthesised as shown in Scheme 1. The literature procedures of McKervey [20] and Gutsche [21] were used to prepare the distal 1,3-terminal bis(carboxylic acid) compound 4 .

\section{Scheme 1}


The 1,3-bis(acid chloride) substituted compound 5 was prepared using a method analogous to that of McKervey [20] where the acid was converted to the acid chloride by heating the acid with thionyl chloride in toluene, at reflux temperature. The less toxic solvent toluene was used in place of benzene, which had been used in the published method, without any reduction in yield. The bis(acid chloride) $\mathbf{5}$ was then separately reacted with each spirolactam (1-3) to give the desired compounds in $49-52 \%$ isolated yields, after column chromatography. However, it was found that in each case the NMR spectra $\left({ }^{1} \mathrm{H}\right.$ and $\left.{ }^{13} \mathrm{C}\right)$ were very complicated because the "product" was a mixture of diastereoisomers, since the spirolactams used were racemic mixtures. All efforts to resolve the spirolactams (1-3), using a number of resolution methods, to provide the individual enantiomers were unsuccessful [22-26]. Therefore, after further very careful column chromatography, small amounts of single diastereoisomer compounds were isolated, with much simplified NMR spectra. Thus far, attempts to obtain crystals of any of these products suitable for X-ray analysis have been unsuccessful, so the relative and absolute stereochemistries of the spiro centres are currently not known.

The synthetic route to the dimethoxy calix[4]arene 1,3-distal substituted spirolactam compounds is also shown in Scheme 1. The literature procedures of Gutsche and McKervey were used to prepare the terminal diester-dimethoxy 1,3-distal calix[4]arene using $\mathrm{NaH}$ and $\mathrm{MeI}$ in THF [20, 21]. The ester groups were subsequently hydrolysed using ethanolic $\mathrm{NaOH}$, followed by $\mathrm{pH}$ adjustment with $3 \mathrm{M} \mathrm{HCl}$ to give the dicarboxylic acid-dimethoxy derivative 10. The product was isolated in $98 \%$ yield after purification by recrystallisation from EtOH/ $\mathrm{H}_{2} \mathrm{O}$ as a white crystalline solid. Reaction with thionyl chloride to provide the diacid-chloride-dimethoxy compound $\mathbf{1 1}$ was conducted using the same conditions as described above and the yield was quantitative. The dimethoxy-spirocyclic calixarenes 12, 13 and 14 were obtained in yields ranging from $45-66 \%$ using the same reaction conditions outlined previously. When the Diamond Group published the synthesis of compounds with methoxy groups in the literature [27], they reported that the ${ }^{1} \mathrm{H}$ NMR spectrum contained several broad signals too close together to assess even using high field techniques, and used accurate mass spectral data to determine that they had obtained the correct compound. This was found to be the case for the spirolactam-dimethoxy derivatives 12-14 also, so accurate mass spectral data (see Table 1), coupled with IR data was used to show that reaction did indeed provide compounds 12, 13 and 14. The broadness of the NMR signals is most likely due to the loss of intramolecular H-bonding at the phenolic oxygen positions, making the calixarene backbone more mobile in solution with rapid conformational fluctuations occurring as a result, something that has been previously documented for calixarenes [27]. A 
detailed NMR conformational study on these calix-spirolactams by VT NMR will be undertaken and reported in the future.

Table 1: $\quad$ HRMS results for the dimethoxy-spirolactam calixarene compounds 12, 13 and 14

\begin{tabular}{|c|c|c|}
\hline Compound $^{*}$ & Calculated & Found \\
\hline$(12+N a)^{+}$ & 1203.6606 & 1203.6609 \\
\hline$(13+H)^{+}$ & 1117.6946 & 1117.6993 \\
\hline$(14+N a)^{+}$ & 1239.7125 & 1239.7126 \\
\hline
\end{tabular}

* Complexation with $\mathrm{Na}^{+}$from the glass vial in which the sample was stored is a common feature for calixarenes [28].

\subsection{Metal Picrate Extraction Studies}

Since Diamond and McKervey developed a $\mathrm{Na}^{+}$ion selective electrode using a calix[4]arene host compound over 20 years ago, numerous calixarene derivatives containing pendant functional groups (e.g. ketones, amides, ethers, crown ethers and esters) have been incorporated in an array of commercial sensor devices capable of sensing alkali and alkaline earth metal guests for many applications [29, 30]. There are some calixarene-based sensors reported for the soft heavy metal ions, like $\mathrm{Ag}^{+}, \mathrm{Pb}^{2+,}$ and $\mathrm{Hg}^{2+}$ which display a strong affinity for soft coordination centres, i.e. N, S, Se and P [31]. Calixarenes with azo and imine units have shown good binding towards metal ions such as $\mathrm{Ca}^{2+}$ and $\mathrm{Ni}^{2+}$, respectively [32-34]. In more recent years a number of calixarene derivatives containing thioether, pyridyl, benzothiazoyl and other heteroatomic arrangements have been synthesised and tested as ionophores for heavy metals [5]. However, while they may bind very well to the guest species, they are generally not always very selective towards any one particular metal ion. This is a significant drawback for commercial application in a sensor or in a more traditional ionselective electrode system.

One of the most useful measures of a host compound's ability for use in an environmental or other type of chemical/bio sensor application is its ability to selectively interact with the sensing agent or guest species. When that agent is an ionic guest it is frequently required to obtain that measurement from an aqueous solution. However, the trapping macrocycles are usually highly organic in nature and hydrophobic. So, if the initial screening of host or sensing compounds is carried out in a biphasic mixture it can provide a strong indicator of how that host would behave in a sensor. In addition, a quantitative measure of the host-guest 
interaction that provides information on selectivity or specificity of binding is vital to direct studies on specific sensor application. The most effective method that satisfies both of these key requirements is the picrate extraction method devised by Pedersen in 1968 and still very much in use today [16]. The spirolactam calix[4]arene compounds were tested against transition heavy metal ion picrates. Some of the smaller alkali and alkaline metal ion picrates salts were used for comparison, since the calix[4]arene cavity has always been selective for $\mathrm{Na}^{+}$, in particular [35]. However, the selectivity is known to be affected by the substituents present, particularly at the narrower lower rim [36-38].

The metal picrate extraction experiments were performed by using a $2.5 \times 10^{-4} \mathrm{M}$ host solution of calix[4]arene compounds in dichloromethane and a picrate solution in deionised water, according to the procedure described by Pedersen [16]. The absorption of the extracted picrate were measured from the aqueous layer at $355 \mathrm{~nm}$ and compared with the blank experiment (with no bis(spirolactam)-calix[4]arene host) of the appropriate picrate. It was found that $1 \mathrm{~h}$ for shaking and then $2 \mathrm{~h}$ for the separation of the two phases was sufficient for achieving equilibrium. The results, expressed as a percentage extraction (\%E) of cation are shown in Table 2 for the spirolactam-calix[4]arenes $\mathbf{6}, \mathbf{7}$ and $\mathbf{8 .}$

Table 2: Extraction $^{\mathrm{a}}(\% \mathrm{E})$ of metal picrates with bis(spirolactam) calixarene hosts

6,7 and 8

\begin{tabular}{|c|c|c|c|c|c|c|c|c|c|c|c|}
\hline Host & $\mathbf{C o}^{2+}$ & $\mathbf{N i}^{\mathbf{2 +}}$ & $\mathbf{C u}^{\mathbf{2 +}}$ & $\mathbf{Z n}$ & $\mathbf{\mathbf { C d } ^ { 2 + }}$ & $\mathbf{P b}$ & $\mathbf{L i}^{\mathbf{2 +}}$ & $\mathbf{N a}^{+}$ & $\mathbf{K}^{+}$ & $\mathbf{C a}^{2+}$ & $\mathbf{M g}^{\mathbf{2 +}}$ \\
\hline $\mathbf{6}$ & 27.9 & 36.6 & 24.8 & 23.5 & 29.0 & $\mathbf{6 3 . 5}$ & 19.7 & 10.0 & 19.6 & 22.4 & 22.1 \\
& $(1.0)$ & $(1.0)$ & $(1.3)$ & $(1.6)$ & $(2.9)$ & $(3.9)$ & $(0.7)$ & $(0.5)$ & $(2.2)$ & $(1.3)$ & $(2.7)$ \\
\hline $\mathbf{7}$ & 0.5 & 0 & 4.0 & 1.0 & 3.9 & $\mathbf{5 6 . 7}$ & 5.0 & 12.9 & 15.8 & 11.2 & 3.4 \\
& $(5.3)$ & $(2.0)$ & $(4.9)$ & $(1.9)$ & $(0.9)$ & $(0.9)$ & $(0.6)$ & $(4.1)$ & $(1.2)$ & $(4.6)$ & $(2.0)$ \\
\hline $\mathbf{8}$ & 20.5 & 8.0 & $\mathbf{7 4 . 9}$ & 26.1 & 19.2 & $\mathbf{7 5 . 3}$ & 25.2 & 24.6 & 18.7 & 29.4 & 27.3 \\
& $(1.5)$ & $(2.3)$ & $(2.6)$ & $(2.2)$ & $(2.1)$ & $(1.0)$ & $(0.8)$ & $(1.0)$ & $(0.8)$ & $(1.7)$ & $(0.4)$ \\
\hline
\end{tabular}

${ }^{a} \mathrm{n}=3$, figures in brackets are relative standard deviation (RSD) values $(0.4-5.3 \%$ range)

In all cases it was found that the new host compounds showed relatively weak extraction of the alkali and alkaline earth metal ions. This would be expected, given the nature of the pendant arms attached to the 1,3distal phenolic rings. Traditionally simple tetra and di-ester linkages were more suited to extraction of those guest species [35-38]. The trends for the extraction of the divalent heavy-metal salts by the spirocyclic distal -OH calixarene host compounds (6-8) are presented graphically in Figure 2.

Figure 2 
The largest extraction capabilities for all three hosts were displayed with $\mathrm{Pb}^{2+}$ ion. The host with a benzyl group attached at the 1,3-distal spirolactam calix[4]arene $\mathbf{8}$, showed the highest $\%$ extraction values, of up to $75 \%$, for both $\mathrm{Pb}^{2+}$ and $\mathrm{Cu}^{2+}$ ions. Host 7, with the pendant allyl groups, demonstrated the highest overall selectivity for $\mathrm{Pb}^{2+}$ over all of the ions used in the study. The host compound $\mathbf{6}$, with the pendant ester groups, demonstrated the least selectivity but with good extraction levels for all heavy metals studied.

When the two remaining $-\mathrm{OH}$ groups of $\mathbf{6 - 8}$ were replaced by $-\mathrm{OCH}_{3}$ groups the extraction ability was measured for a select number of metal ions. There was an overall increase in the \% extraction, as shown in Table 3 for the dimethoxy spirolactam calix[4]arenes $\mathbf{1 2 , 1 3}$ and $\mathbf{1 4}$, with the exception of $\mathrm{Cu}^{2+}$ ion and host compound 14.

Table 3: Extraction $^{\mathrm{a}}(\% \mathrm{E})$ of metal picrates with bis(spirolactam) calixarene hosts 12,13 and 14

\begin{tabular}{|c|c|c|c|c|c|c|}
\hline Host & $\mathbf{C o}^{2+}$ & $\mathbf{N i}^{2+}$ & $\mathbf{C u}^{2+}$ & $\mathbf{Z n}^{2+}$ & $\mathbf{C d}^{2+}$ & $\mathbf{P b}^{2+}$ \\
\hline $\mathbf{1 2}$ & 66.0 & 57.3 & 56.5 & 66.8 & 63.4 & 86.5 \\
\hline $\mathbf{1 3}$ & 62.5 & 64.5 & 47.3 & 50.5 & 50.4 & 64.8 \\
\hline $\mathbf{1 4}$ & 42.1 & 21.6 & 30.0 & 42.7 & 46.5 & 78.5 \\
\hline
\end{tabular}

However, in all cases, 12-14 were found to be less selective for one specific metal guest ion (Figure 3). The highest level of extraction was recorded for compound $\mathbf{1 2}$ with the pendant ester substituents on the spiroalactam unit, at $86.5 \%$ for $\mathrm{Pb}^{2+}$. The most selective of this group of hosts was compound $\mathbf{1 4}$, with the pendant $N$-benzyl groups. Like their -OH analogues, the -OMe compounds (12-14) showed negligible extraction efficiency $(<30 \%)$ towards the alkaline and alkali metal ions (data not shown).

\section{Figure 3}

There is a difference in sensitivity and selectivity for the metal ions between the extractant compounds with phenolic $-\mathrm{OH}$ groups (6-8) and those with $-\mathrm{OCH}_{3}$ groups (12-14). The compilation of all the extraction results (Figure 4) points to preferential extraction of $\mathrm{Pb}^{2+}$, in all cases. The recorded $\%$ extraction for $\mathrm{Pb}^{2+}$ values are comparable to heavily substituted lower rim calix[4]arenes published in the literature [39, 40] and other 1,3-distal substituted calixarene hosts [3-6]. There are reports of calix-crown compounds with higher \% extraction for $\mathrm{Pb}^{2+}$ but they are not as selective as the compounds reported in this study [41-43]. There may 
also be a role for the diastereoisomers of compounds of this study, as different diastereoisomers would be likely to have different effects on both the cavity size and the directionality of the ligating groups of the pendant arms. It is therefore highly probable that the overall extraction capability and selectivity would be influenced by which diastereoisomer was used. However, this is speculative as the stereochemistry of the compounds of this study are not currently known (vide supra) and pure samples of the other diastereoisomers are not currently available.

\section{Figure 4}

\section{Conclusions}

In summary, we have developed a new class of double-armed calix[4]arenes which have demonstrated efficient binding for heavy metal ions over their alkali and alkaline earth metal counterparts. Selectivity for $\mathrm{Pb}^{2+}$ was achieved using compound 7, which had an $N$-allyl substituent on the lactam ring, and this selectivity is a key prerequisite for application in sensor studies. The next step will be the dispersion the spirocyclic calix[4]arenes into a membrane, as a first step in the development of a commercial $\mathrm{Pb}^{2+}$ sensor. We are also currently synthesising calix[4]arenes with different pendant spirocyclic arms in order to try to find even more efficient and selective binders of $\mathrm{Pb}^{2+}$ ions, as well as giving an improved overall understanding of the structure-extraction ability relationship for the spirocyclic double-armed calix[4]arene compounds. The results from all of these studies will be reported in due course.

\section{Experimental}

\subsection{General Methodology}

All solvents used for synthesis were either HPLC of AR grade, purchased from Sigma-Aldrich, Labscan or Lennox. The grade of petroleum ether used was $40-60{ }^{\circ} \mathrm{C}$, unless otherwise stated. All reactions requiring anhydrous conditions were carried out under a nitrogen atmosphere. Flash chromatography was performed using silica gel $(0.040-0.063 \mathrm{~mm}) 60 \AA$, purchased from Sigma-Aldrich. All isolated products were dried under vacuum in advance of characterisation.

Melting point analysis was performed using a Bibby Stewart Scientific SMP1 melting point apparatus and are uncorrected. Elemental analysis was carried out at University College Dublin, Belfield using a CE 440 
Elemental Analyser. Mass Spectrometry analysis was carried out at the Centre for Synthesis and Chemical Biology, University College Dublin, Belfield.

${ }^{1} \mathrm{H}$ and ${ }^{13} \mathrm{C}$ NMR spectroscopy was carried out on a Jeol JNM-LA 300 FT-NMR $300 \mathrm{MHz}$ spectrometer using either $\mathrm{CDCl}_{3}$ or $d$-DMSO, using tetramethyl silane (TMS) as the internal standard, unless otherwise stated. Chemical shifts are expressed in parts per million (ppm, $\delta$ ), downfield from the internal standard. Resolution is $0.18 \mathrm{~Hz}$ or $0.0006 \mathrm{ppm}$ for ${ }^{1} \mathrm{H}$-spectra (coupling constants at $\pm 0.36 \mathrm{~Hz}$ ) and $0.62 \mathrm{~Hz}$ or 0.008 ppm for ${ }^{13} \mathrm{C}$.

Thin layer chromatography (TLC) was carried out with the stated eluent system in a pre-saturated elution tank using silica gel $60 \mathrm{~F}_{254}(20 \mathrm{~cm} \times 20 \mathrm{~cm} \times 0.2 \mathrm{~mm})$ aluminium backed plates. Preparative TLC was carried out using silica gel $60 \mathrm{~F}_{254}$ coated glass plates $(20 \mathrm{~cm}$ x $20 \mathrm{~cm}$ x $1000 \mu \mathrm{m})$. Compounds were detected under ultraviolet light, by development in an iodine tank or by dying with a potassium permanganate solution.

Infrared spectroscopy was carried out using a Nicolet Avatar 320 FT-IR spectrometer running on the "Omnic" software package. Solid samples were prepared as dispersions in $\mathrm{KBr}$ discs and liquid samples as an interspersed film between polished sodium chloride plates.

\subsection{Synthesis}

5,11,17,23-Tetra-tert-butyl-25,27-dichloroformylmethoxy-26,28-dihydroxycalix[4]arene (5) [20, 21]. To calix[4]arene diacid 4 [12, 13] $(5.50 \mathrm{~g}, 7.19 \mathrm{mmol})$ in toluene $(140 \mathrm{ml})$ was added thionyl chloride $(0.41 \mathrm{ml}$, $7.4 \mathrm{mmol}$ ) and the solution was heated at reflux temperature for $2 \mathrm{~h}$. After cooling, the solution was concentrated in vacuo to give a brown solid which was used without further purification $(5.72 \mathrm{~g}, 99 \%) .{ }^{1} \mathrm{H}$ NMR $\left(\mathrm{CDCl}_{3}, \delta \mathrm{ppm}\right) 7.07(4 \mathrm{H}, \mathrm{s}), 6.74(4 \mathrm{H}, \mathrm{s}), 6.14(2 \mathrm{H}, \mathrm{s}), 5.02(4 \mathrm{H}, \mathrm{s}), 4.29(4 \mathrm{H}, \mathrm{d}, J=12.0 \mathrm{~Hz}), 3.41$

$(4 \mathrm{H}, \mathrm{d}, J=12.0 \mathrm{~Hz}), 1.28(18 \mathrm{H}, \mathrm{s}), 0.96(18 \mathrm{H}, \mathrm{s}) ;{ }^{13} \mathrm{C} \mathrm{NMR}\left(\mathrm{CDCl}_{3}, \delta \mathrm{ppm}\right) 169.9,149.8,149.7,142.3$, 131.7, 129.2, 128.2, 127.9, 126.3, 125.4, 78.7, 33.91; 33.90, 31.73, 31.70, 30.9; IR (KBr, $\left.\mathrm{cm}^{-1}\right) 3502,3049$, 3025, 2962, 2905, 2868, 1813.

5,11,17,23-Tetra-tert-butyl-25,27-di(7-methoxycarbonylmethyl-6-oxo-1,7-diaza-spiro[4.4]nonane)-26,28dihydroxycalix[4]arene (6). To a solution of spirolactam trifluoroacetate salt $\mathbf{1}$ [17] (0.75 g, $2.32 \mathrm{mmol})$ in 
dichloromethane $(50 \mathrm{ml})$ at $0{ }^{\circ} \mathrm{C}$ was added triethylamine $(3.25 \mathrm{ml}, 23.2 \mathrm{mmol})$ and the solution was stirred for $30 \mathrm{~min}$ at ambient temperature. To this solution was added dropwise a solution of bis(acid chloride) $\mathbf{5}$ $(0.93 \mathrm{~g}, 1.16 \mathrm{mmol})$ in dichloromethane $(20 \mathrm{ml})$ and the solution was stirred at room temperature for 5 days, then washed with $1 \mathrm{M} \mathrm{HCl}$ solution $(3 \times 20 \mathrm{ml})$, brine $(3 \times 20 \mathrm{ml})$, dried over $\mathrm{MgSO}_{4}$ and concentrated in vacuo. The resulting solid was purified by column chromatography on silica gel in 5\% methanol/dichloromethane to give an off white solid $(0.69 \mathrm{~g}, 51.5 \%)$. Further purification of this mixture of diastereoisomers by column chromatography using $0.5 \%$ methanol/dichloromethane gave an off-white solid (0.14 g (10\%). M.pt. 163-165 ${ }^{\circ} \mathrm{C} ; \mathrm{R}_{\mathrm{f}} 0.26$ (5\% methanol/dichloromethane); ${ }^{1} \mathrm{H}$ NMR $\left(\mathrm{CDCl}_{3}, \delta \mathrm{ppm}\right) 7.41$ (br s, 2H), $7.26\left(\mathrm{CHCl}_{3}\right), 6.97(\mathrm{~s}, 4 \mathrm{H}), 6.77(\mathrm{~s}, 4 \mathrm{H}), 4.80-4.30(\mathrm{~m}, 12 \mathrm{H}), 3.66(\mathrm{~s}, 6 \mathrm{H}), 3.60-3.44(\mathrm{~m}, 4 \mathrm{H})$ 3.42-3.23 (m, 4H), 2.84-2.76 (m, 4H), 2.22-1.95 (m, 12H), $1.23(\mathrm{~s}, 18 \mathrm{H}), 0.95(\mathrm{~s}, 18 \mathrm{H}) ;{ }^{13} \mathrm{C} \mathrm{NMR}\left(\mathrm{CDCl}_{3}, \delta\right.$ ppm) $175.2,169.4,167.2,152.9,151.3,149.3,148.7,132.7,127.7,125.8,125.1,76.4,68.1,52.1,47.8,44.9$, 44.7, 36.6, 34.7, 34.2, 34.1, 31.8, 31.2, 29.7, 24.4; IR $\left(\mathrm{KBr}, \mathrm{cm}^{-1}\right) 3416,2960,2870,1750,1655$; Microanalysis, $\mathrm{C}_{68} \mathrm{H}_{88} \mathrm{~N}_{4} \mathrm{O}_{12} .0 .3 \mathrm{CHCl}_{3}$ requires $\mathrm{C}, 68.98 \%, \mathrm{H}, 7.48 \%, \mathrm{~N}, 4.71 \%$; found $\mathrm{C}, 69.06 \% \mathrm{H}, 7.50 \%$ N, 4.86\%; MS (ES+) calculated for $\mathrm{C}_{68} \mathrm{H}_{88} \mathrm{~N}_{4} \mathrm{O}_{12},[\mathrm{M}+\mathrm{H}]^{+} 1153.6$, found $[\mathrm{M}+\mathrm{H}]^{+}$1153.6.

\section{5,11,17,23-Tetra-tert-butyl-25,27-di(7-allyl-6-oxo-1,7-diaza-spiro[4.4]nonane)-26,28-}

dihydroxycalix[4]arene (7). Spirolactam derivatised calixarene 7 was prepared in a similar manner to that described for 6 using trifluoroacetate salt 2 [17]. A mixture of diastereoisomers was recovered after purification by column chromatography in $5 \%$ methanol/dichloromethane to give an off white solid (0.62 g, 49\%). Further purification, as described above, resulted in the isolation of one diastereoisomer as an off white solid (0.18 g, 14\%). M.pt. $179-181{ }^{\circ} \mathrm{C} ; \mathrm{R}_{\mathrm{f}} 0.32$ (5\% methanol/dichloromethane); ${ }^{1} \mathrm{H}$ NMR $\left(\mathrm{CDCl}_{3}, \delta\right.$ ppm) $7.49(\mathrm{~s}, 2 \mathrm{H}), 6.95(\mathrm{~s}, 4 \mathrm{H}), 6.78(\mathrm{~s}, 4 \mathrm{H}), 5.78-5.72(\mathrm{~m}, 2 \mathrm{H}), 5.32-5.18(\mathrm{~m}, 4 \mathrm{H}), 4.78(\mathrm{~d}, 4 \mathrm{H}, J=15.0$ $\mathrm{Hz}), 4.55(\mathrm{~d}, 4 \mathrm{H}, J=15.0 \mathrm{~Hz}), 4.38-4.34(\mathrm{~m}, 4 \mathrm{H}), 3.94-3.90(\mathrm{~m}, 4 \mathrm{H}), 3.73(\mathrm{~m}, 4 \mathrm{H}), 3.50-3.47(\mathrm{~m}, 2 \mathrm{H}), 3.30-$ $3.25(\mathrm{~m}, 6 \mathrm{H}), 2.18-1.95(\mathrm{~m}, 8 \mathrm{H}), 1.56\left(\mathrm{H}_{2} \mathrm{O}\right), 1.22(\mathrm{~s}, 18 \mathrm{H}), 0.97(\mathrm{~s}, 18 \mathrm{H}) ;{ }^{13} \mathrm{C} \mathrm{NMR}\left(\mathrm{CDCl}_{3}, \delta \mathrm{ppm}\right) 173.6$, $166.6,151.1,149.9,147.3,141.9,133.6,130.5,132.7,125.6,125.0,122.6,74.7,65.3,49.8,47.4,43.5,34.6$, 34.3, 34.0, 31.6, 31.0, 27.6, 24.8; IR (KBr, $\left.\mathrm{cm}^{-1}\right)$ 3426, 2959, 2870, 1694, 1652, 1648, 901; Microanalysis, $\mathrm{C}_{68} \mathrm{H}_{88} \mathrm{~N}_{4} \mathrm{O}_{8}$ requires $\mathrm{C}, 74.97 \%, \mathrm{H}, 8.14 \%, \mathrm{~N}, 5.14 \%$; found $\mathrm{C}, 74.66 \%, \mathrm{H}, 7.54 \%, \mathrm{~N}, 4.54 \%$; MS (ES $\left.{ }^{+}\right)$ calculated for $\mathrm{C}_{68} \mathrm{H}_{88} \mathrm{~N}_{4} \mathrm{O}_{8}$, expected $[\mathrm{M}+\mathrm{H}]^{+}$1089.7, found $[\mathrm{M}+\mathrm{H}]^{+} 1089.7$.

\section{5,11,17,23-Tetra-tert-butyl-25,27-di(7-benzyl-6-oxo-1,7-diaza-spiro[4.4]nonane)-26,28-}

dihydroxycalix[4]arene (8). Spirolactam derivatised calixarene 8 was prepared in a similar manner to that 
described for $\mathbf{6}$ using trifluoroacetate salt 3 [11a]. A solid residue was purified was purified by column chromatography on silica gel with $5 \%$ methanol/dichloromethane to give an off white solid $(0.72 \mathrm{~g}, 52 \%)$ and further purified to give one diastereoisomer as an off white solid (0.12 g, 9\%). M.pt. $264-266{ }^{\circ} \mathrm{C} ; \mathrm{R}_{\mathrm{f}} 0.21$ (5\% methanol/dichloromethane); ${ }^{1} \mathrm{H}$ NMR $\left(\mathrm{CDCl}_{3}, \delta \mathrm{ppm}\right) 7.39(\mathrm{~s}, 2 \mathrm{H}), 7.34-7.22(\mathrm{~m}, 10 \mathrm{H}), 6.98(\mathrm{~s}, 4 \mathrm{H})$, $6.78(\mathrm{~s}, 4 \mathrm{H}), 4.93-4.40(\mathrm{~m}, 12 \mathrm{H}), 3.94-3.71(\mathrm{~m}, 4 \mathrm{H}) 3.37-3.26(\mathrm{~m}, 4 \mathrm{H}), 2.78-2.62(\mathrm{~m}, 2 \mathrm{H}), 2.19-1.85(\mathrm{~m}$, 14H), $1.56\left(\mathrm{H}_{2} \mathrm{O}\right), 1.24$ (s, $\left.18 \mathrm{H}\right), 0.97(\mathrm{~s}, 18 \mathrm{H}) ;{ }^{13} \mathrm{C} \mathrm{NMR}\left(\mathrm{CDCl}_{3}, \delta \mathrm{ppm}\right) 173.6,166.6,151.5,150.4,146.9$, $141.2,136.3,132.7,132.1,129.1,128.7,128.0,127.8,126.8,127.7,125.4,73.9,68.3,47.6,47.2,43.2,36.8$, 34.4, 34.2, 33.8, 31.6, 31.0, 29.8, 24.4; IR (KBr, $\left.\mathrm{cm}^{-1}\right)$ 3421, 2961, 2868, 1697, 1655; Microanalysis, $\mathrm{C}_{76} \mathrm{H}_{92} \mathrm{~N}_{4} \mathrm{O}_{8} .3 .5 \mathrm{H}_{2} \mathrm{O}$ requires $\mathrm{C}, 72.87 \%, \mathrm{H}, 7.97 \%, \mathrm{~N}, 4.47 \%$; found $\mathrm{C}, 72.71 \%, \mathrm{H}, 7.88 \%, \mathrm{~N}, 4.94 \%$; MS $\left(\mathrm{ES}^{+}\right)$calculated for $\mathrm{C}_{76} \mathrm{H}_{92} \mathrm{~N}_{4} \mathrm{O}_{8}$, expected $[\mathrm{M}+\mathrm{H}]^{+}$1189.7, found $[\mathrm{M}+\mathrm{H}]^{+} 1189.7$.

5,11,17,23-Tetra-tert-butyl-25,27-dicarboxymethoxy-26,28-dimethoxycalix[4]arene (10). To a solution of 5,11,17,23-tetra-tert-butyl-25,27-diethoxycarbonyl methyleneoxy-26,28-dihydroxycalix[4]arene [20, 21, 27] (4.0 g, $4.7 \mathrm{mmol})$ in THF (40 ml) was added sodium hydride $(0.56 \mathrm{~g}, 23.5 \mathrm{mmol})$ and the mixture was stirred for $30 \mathrm{~min}$ at ambient temperature. A solution of iodomethane $(0.65 \mathrm{ml}, 10.34 \mathrm{mmol})$ in THF (5 ml) was then added dropwise and the solution was stirred at room temperature for $16 \mathrm{~h}$. Water $(5 \mathrm{ml})$ was added and the solution was concentrated in vacuo. The solid residue was dissolved in dichloromethane (30 ml), washed with $10 \%$ aqueous $\mathrm{HCl}$ solution $(10 \mathrm{ml})$, water $(3 \times 10 \mathrm{ml})$, dried over $\mathrm{MgSO}_{4}$ and concentrated in vacuo. 5,11,17,23-Tetra-tert-butyl-25,27-diethoxycarbonyl methyleneoxy-26,28, dimethoxycalix[4]arene was recovered from methanol as a white solid (3.12 g, 74\%). M.pt. $181-183{ }^{\circ} \mathrm{C} ; \mathrm{R}_{\mathrm{f}} 0.69$ (5\% ethyl acetate/petroleum ether); IR (KBr, $\left.\mathrm{cm}^{-1}\right)$ 2961, 2821, 1763.

To a suspension of 5,11,17,23-tetra-tert-butyl-25,27-diethoxycarbonyl methyleneoxy-26,28, dimethoxycalix[4]arene $(3.0 \mathrm{~g}, 3.5 \mathrm{mmol})$ in ethanol $(80 \mathrm{ml})$ was added $15 \%$ aqueous $\mathrm{NaOH}$ solution (12 $\mathrm{ml}$ ) and the solution was heated to reflux temperature for $24 \mathrm{~h}$, cooled and concentrated in vacuo. The resulting solid was suspended in $\mathrm{H}_{2} \mathrm{O}(80 \mathrm{ml})$ and the $\mathrm{pH}$ of the mixture was adjusted to 1 using $3 \mathrm{M}$ aqueous $\mathrm{HCl}$ solution. The resulting solid was isolated by vacuum filtration, dissolved in dichloromethane (50 ml), washed with $3 \mathrm{M} \mathrm{HCl}(10 \mathrm{ml})$, water $(3 \times 10 \mathrm{ml})$, dried over $\mathrm{MgSO}_{4}$ and concentrated in vacuo. Calix[4]arene 10 was recovered as a white solid from ethanol/water $(2.56 \mathrm{~g}, 98 \%)$. M.pt. $259-261{ }^{\circ} \mathrm{C} ; \mathrm{R}_{\mathrm{f}} 0.63(10 \%$ methanol/dichloromethane); IR (KBr, $\left.\mathrm{cm}^{-1}\right)$ 3500-3200, 2962, 2869, 1760. 
5,11,17,23-Tetra-tert-butyl-25,27-dichloroformylmethoxy-26,28-dimethoxycalix[4]arene (11). To a solution of calixarene $10(2.0 \mathrm{~g}, 2.73 \mathrm{mmol})$ in toluene $(30 \mathrm{ml})$ was added thionyl chloride $(0.15 \mathrm{ml}, 2.8 \mathrm{mmol})$ and the solution was heated to reflux temperature for $2 \mathrm{~h}$, cooled and concentrated in vacuo to give a brown solid $(2.08 \mathrm{~g}, 99 \%) . \mathrm{IR}\left(\mathrm{KBr}, \mathrm{cm}^{-1}\right) 2963,2868,1809$.

\section{5,11,17,23-Tetra-tert-butyl-25,27-di(7-methoxycarbonylmethyl-6-oxo-1,7-diaza-spiro[4.4]nonane)-26,28-}

dimethoxycalix[4]arene (12). Spirolactam derivatised calixarene 12 was prepared in a similar manner to that described for $\mathbf{6}$ using trifluoroacetate salt $\mathbf{1}$ [17]. A solid residue was purified by column chromatography on silica gel in $5 \%$ methanol/dichloromethane to give an off white solid $(0.19 \mathrm{~g}, 58 \%)$. M.pt. $146-148{ }^{\circ} \mathrm{C} ; \mathrm{R}_{\mathrm{f}}$ 0.28 (5\% methanol/dichloromethane); IR $\left(\mathrm{KBr}, \mathrm{cm}^{-1}\right)$ 2961, 2868, 1753, 1749, 1649; HRMS (ES $\left.{ }^{+}\right)$calculated for $\mathrm{C}_{70} \mathrm{H}_{92} \mathrm{~N}_{4} \mathrm{NaO}_{12}$, expected $[\mathrm{M}+\mathrm{Na}]^{+}$1203.6606, found $[\mathrm{M}+\mathrm{Na}]^{+} 1203.6609$.

\section{5,11,17,23-Tetra-tert-butyl-25,27-di(7-Allyl-6-oxo-1,7-diaza-spiro[4.4]nonane)-26,28-}

dimethoxycalix[4]arene (13). Spirolactam derivatised calixarene 13 was prepared in a similar manner to that described for 12 using trifluoroacetate salt 2 [17]. A solid residue was purified was purified by column chromatography on silica gel with $5 \%$ methanol/dichloromethane to give $\mathbf{1 3}$ as an off white solid (0.17 g, 54\%). M.pt. 152-154 ํㅡ; $\mathrm{R}_{\mathrm{f}} 0.36$ (5\% methanol/dichloromethane); IR (KBr, cm $\left.{ }^{-1}\right)$ 2960, 2873, 1690, 1651, 1649, 898; HRMS $\left(\mathrm{ES}^{+}\right)$calculated for $\mathrm{C}_{70} \mathrm{H}_{92} \mathrm{~N}_{4} \mathrm{O}_{8}$, expected $[\mathrm{M}+\mathrm{H}]^{+}$1117.6946, found $[\mathrm{M}+\mathrm{H}]^{+}$1117.6993.

\section{5,11,17,23-Tetra-tert-butyl-25,27-di(7-allyl-6-oxo-1,7-diaza-spiro[4.4]nonane)-26,28-}

dimethoxycalix[4]arene (14). Spirolactam derivatised calixarene 14 was prepared in a similar manner to that described for 12 using trifluoroacetate salt 3 [17]. A solid residue was purified was purified by column chromatography on silica gel with $5 \%$ methanol/dichloromethane to give $\mathbf{1 4}$ as an off white solid $(0.21 \mathrm{~g}$, $66 \%$ ). M.pt. 232-234 ํㅜ; $\mathrm{R}_{\mathrm{f}} 0.25$ (5\% methanol/dichloromethane); IR (KBr, $\left.\mathrm{cm}^{-1}\right)$ 2963, 2870, 1699, 1656; HRMS $\left(\mathrm{ES}^{+}\right.$) calculated for $\mathrm{C}_{78} \mathrm{H}_{96} \mathrm{~N}_{4} \mathrm{O}_{8}$, expected $[\mathrm{M}+\mathrm{Na}]^{+}: 1239.7125$, found $[\mathrm{M}+\mathrm{Na}]^{+} 1239.7126$.

\subsection{Binding Studies.}

Picrate extraction experiments were performed following Pedersen's procedure [16]. All inorganic compounds were reagent grade, and all solvents and available organic materials were commercial products used without purification. A $2.5 \times 10^{-4}$ solution of picric acid was prepared by dissolving $57.2 \mathrm{mg}$ of picric acid in 1 litre of deionised water water. Heavy metal ion stock solutions $(0.01 \mathrm{M})$ were prepared by 
dissolving appropriate amounts of metal salts in $2 \% \mathrm{w} / \mathrm{v} \mathrm{HNO}_{3}$ or $\mathrm{HCl}$ solutions to prevent hydrolysis. Dichloromethane was used as received (analytical grade). Solutions of compounds 6-8 and 12-14 were made in $10 \mathrm{ml}$ of $\mathrm{CH}_{2} \mathrm{Cl}_{2}$ solvent and made up to $100 \mathrm{ml}$. The concentration of spirolactam-calix[4]arene compounds were $2.5 \times 10^{-4} \mathrm{M}$. The metal picrate solutions were prepared by the stepwise addition $10 \mathrm{ml}$ of $0.01 \mathrm{M}$ metal ion stock solution to $10 \mathrm{ml}$ of $2.5 \times 10^{-4} \mathrm{M}$ picric acid made up to $100 \mathrm{ml}$ with deionised water and shaken at $25{ }^{\circ} \mathrm{C}$ for $1 \mathrm{~h}$. Mixing of $10 \mathrm{ml}$ of metal picrate solution with $10 \mathrm{ml}$ of spirolactamcalix[4]arene solution was carried out in stoppered plastic tubes. Complete mixing was achieved using a mechanical water bath shaker for $1 \mathrm{~h}$ and the biphasic solution was left standing for an additional $2 \mathrm{~h}$. The water bath temperature was kept at a constant $25^{\circ} \mathrm{C}$ throughout. The concentration of the picrate metal ions remaining in the aqueous phase was then determined spectrophotometrically at $355 \mathrm{~nm}$. Blank experiments showed that no picrate extraction occurred in the absence of the spirolactam-calix[4]arene compounds. The average of three samples is reported with the RSD of $<5 \%$, in all cases.

The \% extraction values of various ions, shown in Figures 3-4, were calculated using the following equation:

$$
\% \mathrm{E}=100 \times \frac{\left(\mathrm{A}_{1}-\mathrm{A}\right)}{\mathrm{Ao}}
$$

Where $\mathrm{A}_{0}$ is the absorbance of the $2.5 \times 10^{-4}$ metal picrate solution originally

A is the absorbance of the picrate salt in the aqueous layer after extraction

$A_{1}$ is the absorbance from of the blank experiments in the absence of spirolactam-calix[4]arene

Funding: J.W. funded by Strand I of the Irish Government's National Development Plan Technological Sector Research Program and the ITT Dublin PhD Continuation Fund. The work of L.L. was supported by QUESTOR Centre, Belfast and Dublin City University.

Conflict of Interest: The authors declare that they have no conflict of interest.

\section{References}

1. Awual, M., Hasan, M., Shahat, A: Functionalized novel mesoporous adsorbent for selective lead(II) ions monitoring and removal from wastewater. Sensor Actuat. B - Chem 203, 854-863 (2014) 
2. Hashim, M., Mukhopadhyay S., Narayan Sahu, J., Sengupta, B: J. Environ. Manage. 92, 2355-2388 (2011)

3. Chinta, J., Ramanujam, P., Rao, C.: Structural aspects of the metal ion complexes of the conjugates of calix[4]arene: Crystal structures and computational models. Coord. Chem. Rev. 256, 2762-2794 (2012).

4. Joseph, R., Rao, C.: Ion and Molecular Recognition by Lower Rim 1,3-Di-conjugates of Calix[4]arene as Receptors. Chem. Rev. 111, 4658-4702 (2011)

5. Creaven, B., Donlon, D., McGinley, J.: Coordination chemistry of calix[4]arene derivatives with lower rim functionalisation and their applications. Coord. Chem. Rev. 253, 893-962 (2009).

6. Jose, P., Menon, S.: Lower-rim substituted calixarenes and their applications. Bioinorg. Chem. Appl. Article number 65815 (2007)

7. Baekeland, L.H.: The chemical constitution of resinous phenolic condensation products. Ind. Eng. Chem. 5, 506-511 (1913)

8. Zinke, A., Ziegler, E.: Zur Kenntnis des Härtungsprozesses von Phenol-Formaldehyd-Harzen, X. Mitteilung. Chem. Ber. 77B, 264-272 (1944)

9. Zinke, A., Ott. R., Garrana, F.H.: Zur Kenntnis des Härtungsprozesses von Phenol-FormaldehydHarzen. Monatsh. Chem. 89, 135-142 (1958)

10. Cornforth, J.W., Hart, P., Nicholls, G., Rees, R., Stock, J.: Antituberculous effects of certain surface-active polyoxyethylene ethers. Br. J. Pharmacol. 10, 73-86 (1955)

11. Gutsche, C.D., Muthukrishnan, R.: Calixarenes. 1. Analysis of product mixtures produced by basecatalyzed condensation of formaldehyde with para-substituted phenols. J. Org. Chem. 43, 49054906 (1978)

12. Supian, F.L., Richardson, T.H., Deasy, M., Kelleher, F., Ward, J.P., McKee, V.: Interaction between Langmuir and Langmuir-Blodgett Films of Two Calix[4]arenes with Aqueous Copper and Lithium Ions. Langmuir 26, 10906-10912 (2010)

13. Rios, R.: Enantioselective methodologies for the synthesis of spiro compounds. Chem. Soc. Rev. 41, 1060-1074, (2012)

14. Kotha, S., Deb, A.C., Lahiri, K., Manivannan, E.: Selected Synthetic Strategies to Spirocyclics. Synthesis 165-193 (2009)

15. Sacchetti, A., Silvani, A., Lesma, G., Pilati, T.: Phe-Ala-Based Diazaspirocyclic Lactam as Nucleator of Type II ' beta-Turn. J. Org. Chem. 76, 833-839 (2011) and references cited therein 
16. Pedersen, C.J.: Ionic complexes of macrocyclic polyethers. Fed. Proc. 27, 1305-1309 (1968)

17. Kelleher, F., Kelly, S., McKee, V.: Spirobicyclic diamines. Part 3: Synthesis and metal complexation of proline-derived [4.4]-spirodiamines. Tetrahedron 62, 9235-9242 (2007)

18. Kelleher, F., Kelly, S.: Spirobicyclic diamines. Part 2: Synthesis of homochiral diastereoisomeric proline derived [4.4]-spirolactams. Tetrahedron Lett. 47, 5247-5250 (2006)

19. Kelleher, F., Kelly, S.: Spirobicyclic diamines 1: synthesis of proline-derived spirolactams via thermal intramolecular ester aminolysis. Tetrahedron Lett. 47, 3005-3008 (2006)

20. Collins, E.M., McKervey, M.A., Madigan, E., Moran, M.B., Owens, M., Ferguson, G., Harris, S. J.: Chemically modified calix[4]arenes - Regioselective synthesis of 1,3-distal derivatives and related compounds - X-ray crystal-structure of a diphenol dinitrile. Perkin Trans. I 3137-3142 (1991)

21. Gutsche, C.D., Dhawan, B., Levine, J.A., No, K.H., Bauer, L.J.: Calixarenes-9 - Conformational isomers of the ethers and esters of calix[4]arenes. Tetrahedron 39, 409-426 (1983)

22. Kozma, D.: CRC Handbook of Optical Resolutions via Diastereomeric Salt Formation, CRC Press (2002)

23. Fogassy, E., Nogradi, M., Kozma, D., Egri, G., Palovics E., Kiss, V.: Optical Resolution Methods. Org. Biomol. Chem. 4, 3011-3030 (2006)

24. Sakai, K., Yokoyama, M., Sakurai, R., Hirayama, N.: Resolution of 1-cyclohexylethylamine via diastereomeric salt formation with enantiopure 2-phenylacetic acids. Tetrahedron: Asymmetry 17, $1541-1543(2006)$

25. Rouhi, A.M.: Chiral business. Chem. Eng. News 81, 45-61 (2003)

26. Leon, P., Largeau, D., Durand, T., O’Brien, M., Powers, M.: L-tartaric acid salt of a (1R) diastereomer of a 2-azadihydroxybicyclo[2.2.1]heptane compound and the preparation of 2azabicyclo[2.2.1]heptane compounds. United States Patent No. US5886192 (1999)

27. O’Malley, S., Schazmann, B., Diamond, D., Nolan, K.: Preparation and sensor evaluation of a Pacman phthalocyanine. Tetrahedron Lett. 48, 9003-9007 (2007)

28. Duggan, P.J., Sheahan, S.L., Szydzik, M.L.: Crystal and solution structures of 25,27diethoxycarbonylmethoxy-26,28-dimethoxy-t-butylcalix[4] arene. Tetrahedron Lett. 41, 3165-3168 (2000)

29. Cadogan, A., Deasy, M., Diamond, D., McKervey, M.A.: Sodium-selective polymeric membrane electrodes based on calix[4]arene ionophores. Analyst 114, 1551-1554 (1989)

30. Diamond, D.; McKervey, M.A.: Calixarene-based sensing agents. Chem. Soc. Rev. 25, 15-24 (1996) 
31. Gutsche, C.D. Calixarenes, an Introduction: Monographs in Supramolecular Chemistry Royal Society of Chemistry, London (2008)

32. Dong, Y., Kim, T.H., Kim, H.J., Lee, M.H., Lee, S.Y., Mahajan, R.K., Kim, H., Kim, J.S.: Spectroscopic and electrochemical studies of two distal diethyl ester azocalix[4]arene derivatives. J. Electroanal. Chem. 628, 119-124 (2009)

33. Kumar, M., Babu, J.N., Bhalla, V., Kumar, R.: Ratiometric/'On-Off' sensing of Pb2+ ion using pyrene-appended calix[4]arenes. Sensor Actuat. B - Chem. 144, 183-191 (2010)

34. Ward, J.P., White, J.M., Young, C.G.: Synthesis, characterization and metal ion complexation and extraction capabilities of calix[4]arene Schiff base compounds. Tetrahedron 69, 8824-8830 (2013)

35. Arnaud-Neu, F., Collins, E.M., Deasy, M., Ferguson, G., Harris, S.J., Kaitner, B., Lough, A.J., McKervey, M.A., Marques, E., Ruhl, B., Schwing-Weill, M.J., Seward, E.M.: Synthesis, X-ray crystal-structures, and cation-binding properties of alkyl calixaryl esters and ketones, a new family of macrocyclic molecular receptors. J. Am. Chem. Soc. 111, 8681-8691 (1989)

36. Yagi, K., Khoo, S.B., Sugawara, M., Sakaki, T., Shinkai, S., Odashima, K., Umezawa, Y.: Channel mimetic sensing membranes for alkali metal cations based on oriented monolayers of calixarene esters. J. Electroanal. Chem. 401, 65-79 (1996)

37. Chawla, H.M., Singh, S.P., Sahu, S.N., Upreti, S.: Synthesis of calix[4]arene(amido)monocrowns and their photoresponsive derivatives. Tetrahedron 62, 9758-9768 (2006)

38. Solangi, I.B., Memon, S., Bhanger, M.I.: Synthesis and application of a highly efficient tetraester calix[4]arene based resin for the removal of $\mathrm{Pb}^{2+}$ from aqueous environment. Anal. Chim. Acta 638, $146-153(2009)$

39. Quiroga-Campano, C., Gómez-Machuca, H., Jullian, C., De la Fuente, J., Pessoa-Mahana, H., Saitz, C.: Study by fluorescence of calix[4]arenes bearing heterocycles with divalent metals: highly selective detection of $\mathrm{Pb}^{2+}$. J. Incl. Phenom. Macro. 79, 161-169 (2014)

40. Ak, M., Taban, D., Deligoz, H.: Transition metal cations extraction by ester and ketone derivatives of chromogenic azocalix[4]arenes. J. Hazard. Mater., 154, 51-54 (2008)

41. Roundhill, D.M., Solangi, I.B., Memon, S., Bhanger, M.I., Yilmaz, M.: The Liquid-Liquid Extraction of Toxic Metals (Cd, Hg and Pb) by Calixarenes. Pak. J. Anal. Environ. Chem., 10, 1-13 (2009)

42. Tu, C., Surowiec, K., Bartsch, R.A.: Novel calix[4]arene-thiacrown ether for selective and efficient extraction of $\mathrm{Ba}(\mathrm{II}), \mathrm{Pb}(\mathrm{II})$, and $\mathrm{Hg}(\mathrm{II})$. J. Incl. Phenom. Macro. 58, 361-366 (2007) 
43. Yang, Y.: Synthesis of Novel Calix[4]arene-Based Ligands for Selective Metal Cation Extraction.

Ph.D. Thesis, Texas Tech University (2009) (http://hdl.handle.net/2346/11882)

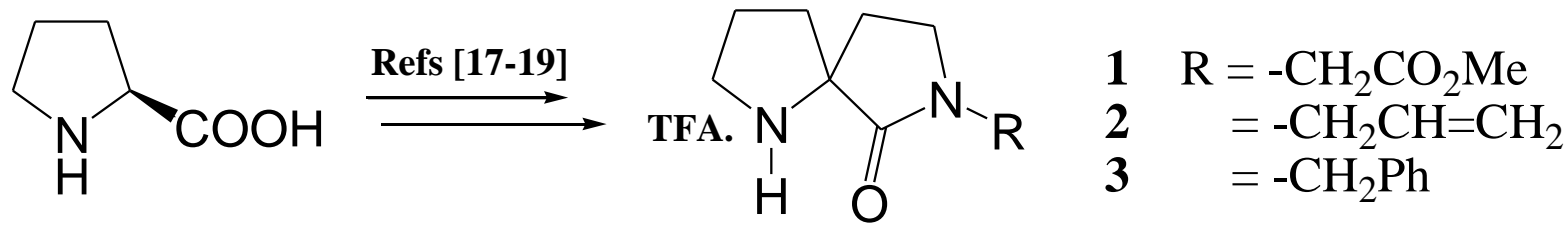

Figure 1. Synthesis of proline-derived spirolactam trifluoroacetate salts 1-3 [17-19]

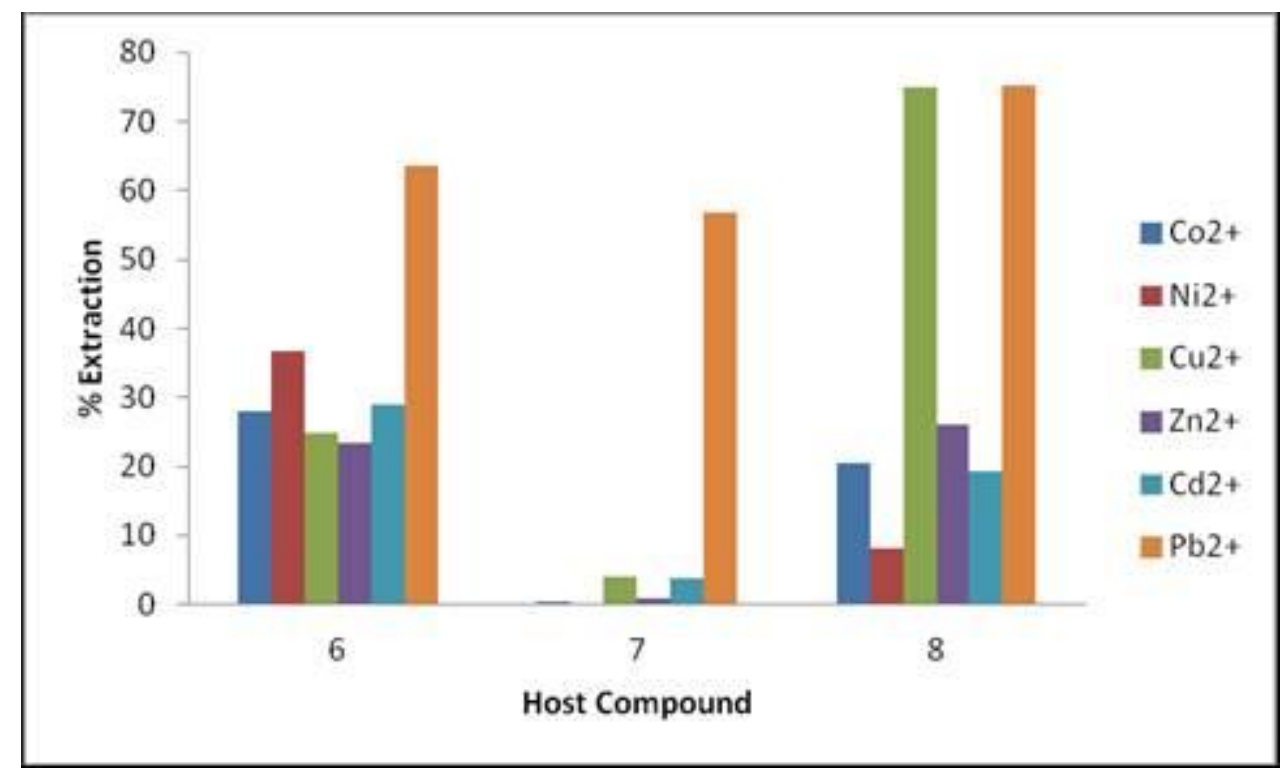

Figure 2: \% Extraction of the heavy metal divalent ion picrate salts from aqueous solution into dichloromethane by spirolactam-calix[4]arene host compounds 6-8, with lower rim phenolic groups 


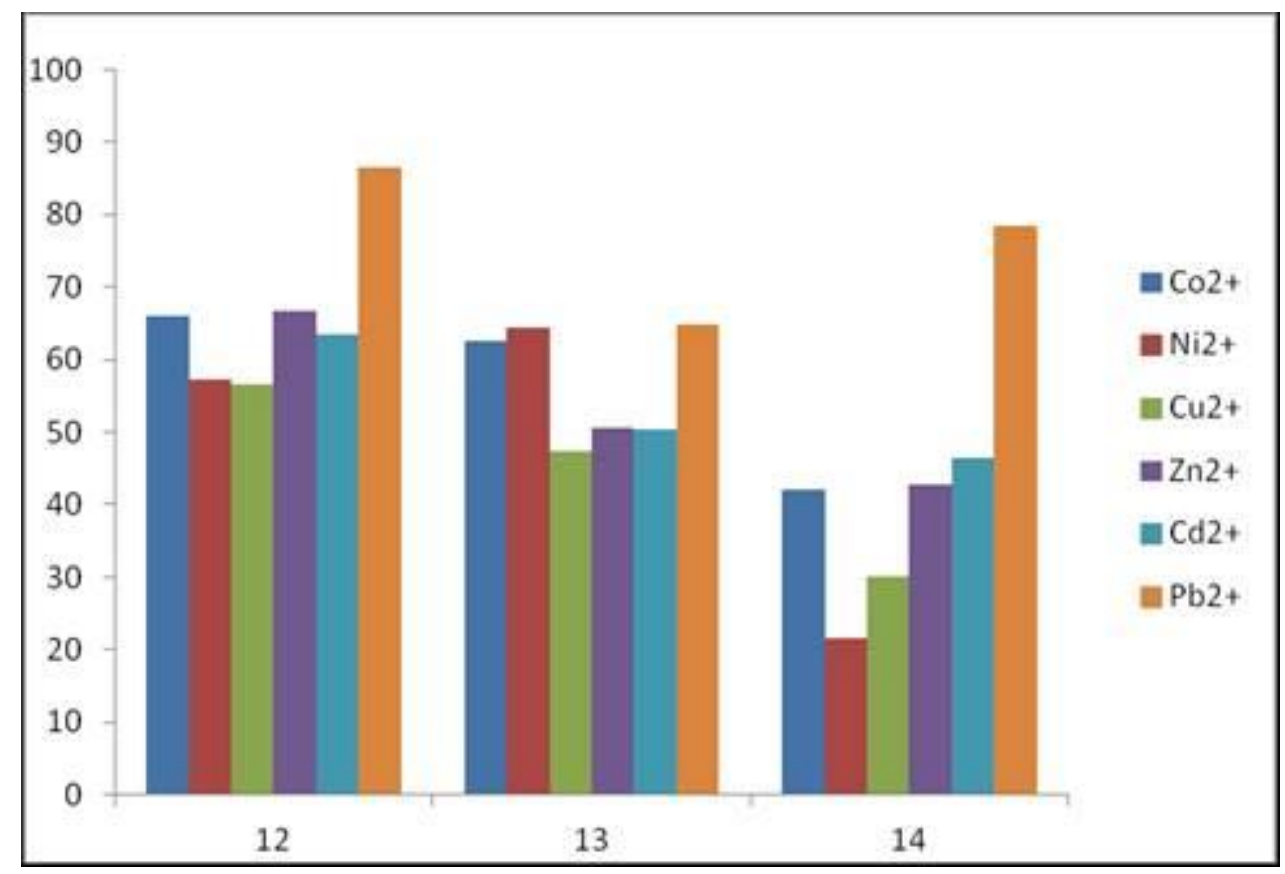

Figure 3: $\quad \%$ Extraction of the heavy metal divalent ion picrate salts from aqueous solution into dichloromethane by spirolactam-calix[4]arene host compounds 12-14, with lower rim methoxy groups.

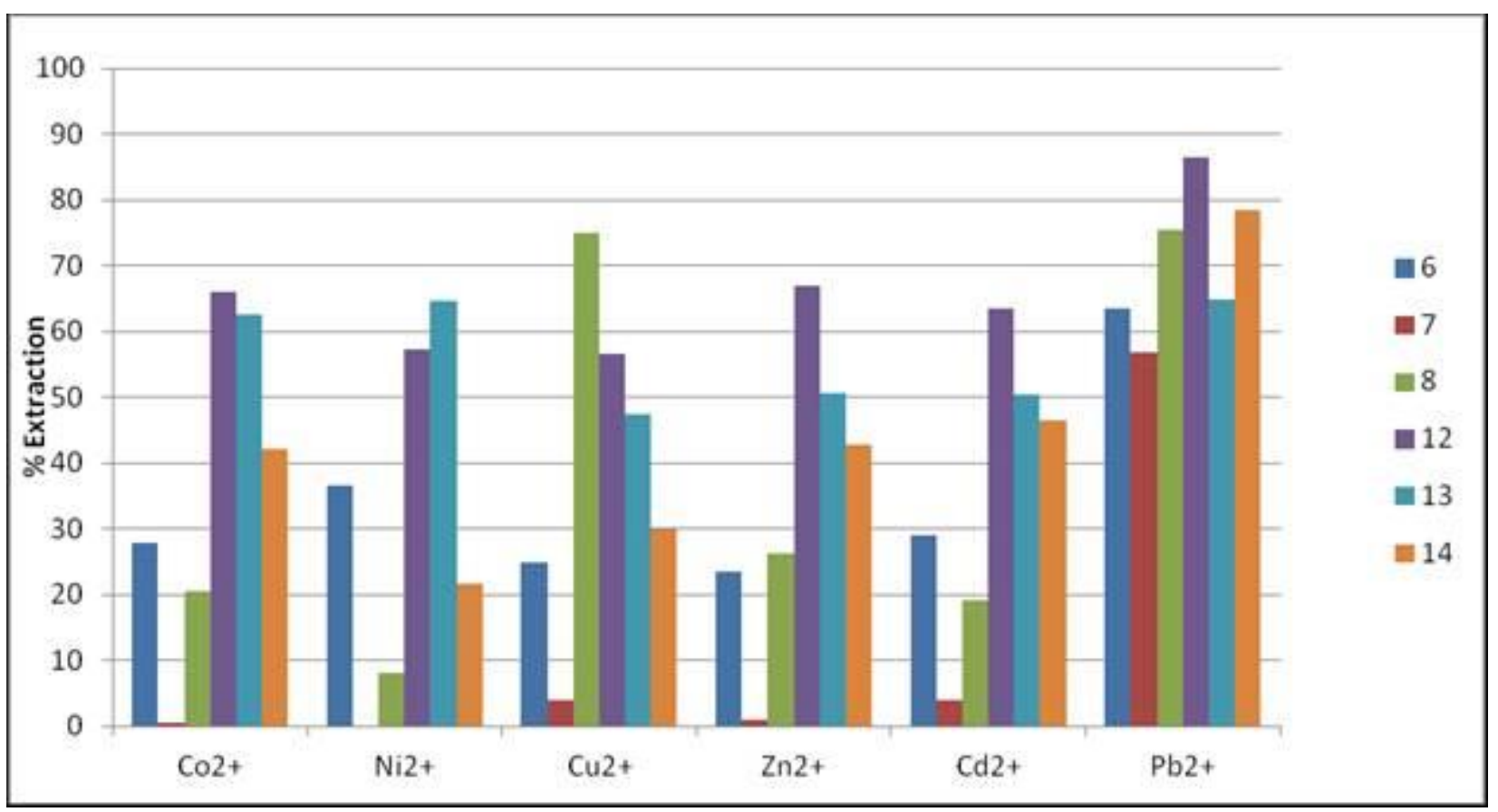

Figure 4: $\quad$ Trend in \% extraction by metal ion for all host compounds 6-8 and 12-14 

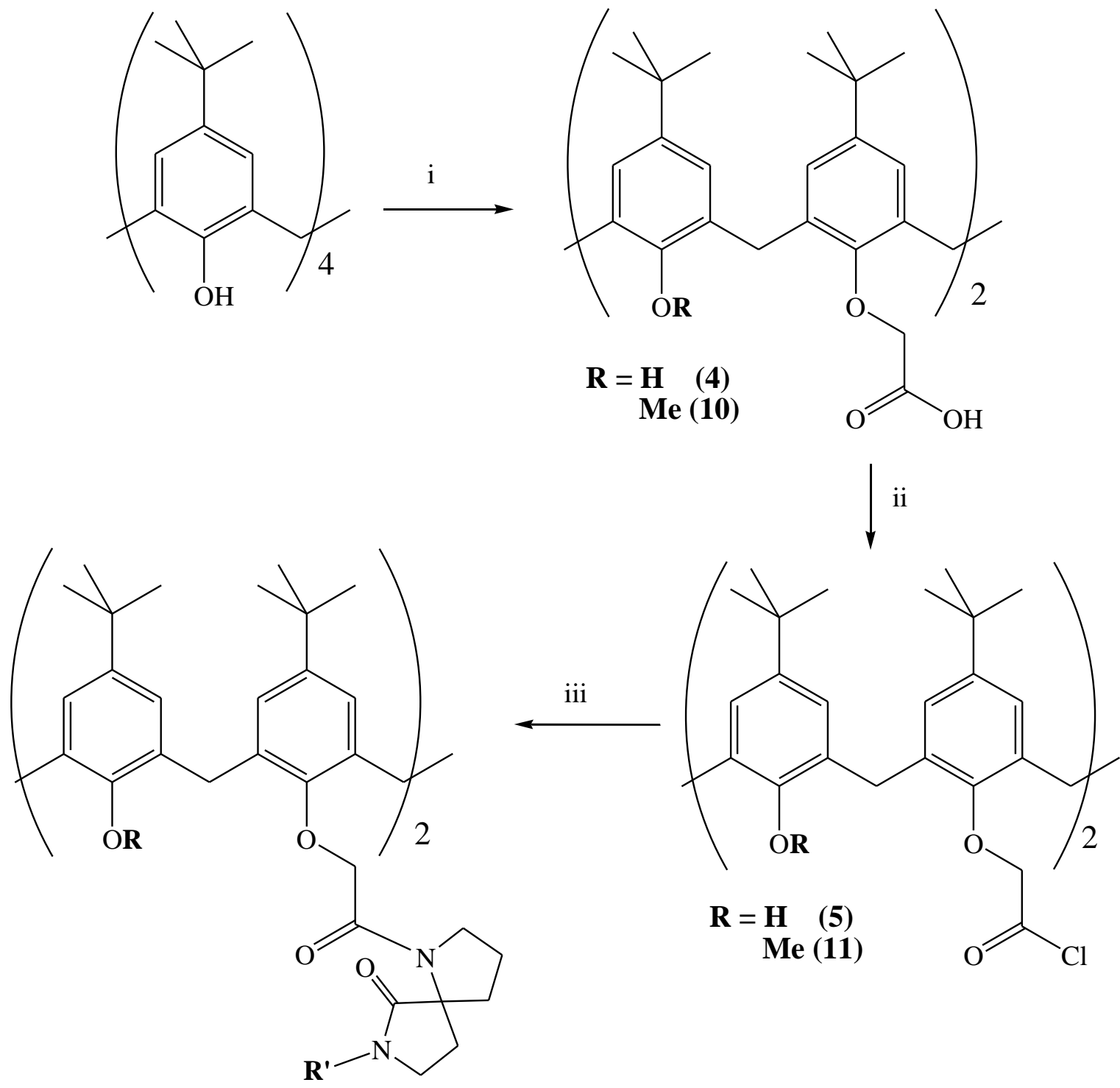

$$
\begin{aligned}
& \mathrm{R}=\mathrm{H} ; \quad \mathrm{R}^{\prime}=-\mathrm{CH}_{2} \mathrm{CO}_{2} \mathrm{CH}_{3} \quad \text { (6) } \\
& -\mathrm{CH}_{2} \mathrm{CH}=\mathrm{CH}_{2} \\
& -\mathrm{CH}_{2}-\mathrm{Ph} \\
& \mathrm{R}=\mathrm{Me} ; \mathbf{R}^{\prime}=-\mathrm{CH}_{2} \mathrm{CO}_{2} \mathrm{CH}_{3} \\
& -\mathrm{CH}_{2} \mathrm{CH}=\mathrm{CH}_{2} \\
& -\mathrm{CH}_{2}-\mathrm{Ph}
\end{aligned}
$$

Reagents and Conditions: i) Refs [20] and [21]; ii) Thionyl chloride, toluene, reflux temperature; iii) 1,2 or $3, \mathrm{Et}_{3} \mathrm{~N}, \mathrm{DCM}$, rt.

Scheme 1. 
Table 1: HRMS results for the dimethoxy-spirolactam calixarene compounds 12, 13 and 14

\begin{tabular}{|c|c|c|}
\hline Compound* $^{*}$ & Calculated & Found \\
\hline$(12+N a)^{+}$ & 1203.6606 & 1203.6609 \\
\hline$(13+H)^{+}$ & 1117.6946 & 117.6993 \\
\hline$(14+N a)^{+}$ & 1239.7125 & 1239.7126 \\
\hline
\end{tabular}

* Complexation with $\mathrm{Na}^{+}$from the glass vial in which the sample was stored is a common feature for calixarenes [16].

Table 2: Extraction $^{\mathrm{a}}(\% \mathrm{E})$ of metal picrates with bis(spirolactam) calixarene hosts

6,7 and 8

\begin{tabular}{|c|c|c|c|c|c|c|c|c|c|c|c|}
\hline Host & $\mathrm{Co}^{2+}$ & $\mathrm{Ni}^{2+}$ & $\mathrm{Cu}^{2+}$ & $\mathrm{Zn}^{2+}$ & $\mathrm{Cd}^{2+}$ & $\mathbf{P b}^{2+}$ & $\mathbf{L i}^{+}$ & $\mathrm{Na}^{+}$ & $\mathbf{K}^{+}$ & $\mathrm{Ca}^{2+}$ & $\mathrm{Mg}^{2+}$ \\
\hline 6 & $\begin{array}{l}27.9 \\
(1.0)\end{array}$ & $\begin{array}{l}36.6 \\
(1.0)\end{array}$ & $\begin{array}{l}24.8 \\
(1.3)\end{array}$ & $\begin{array}{l}23.5 \\
(1.6)\end{array}$ & $\begin{array}{l}29.0 \\
(2.9)\end{array}$ & $\begin{array}{l}\mathbf{6 3 . 5} \\
(3.9)\end{array}$ & $\begin{array}{l}19.7 \\
(0.7)\end{array}$ & $\begin{array}{l}10.0 \\
(0.5)\end{array}$ & $\begin{array}{l}19.6 \\
(2.2)\end{array}$ & $\begin{array}{l}22.4 \\
(1.3)\end{array}$ & $\begin{array}{l}22.1 \\
(2.7)\end{array}$ \\
\hline 7 & $\begin{array}{c}0.5 \\
(5.3)\end{array}$ & $\begin{array}{c}0 \\
(2.0)\end{array}$ & $\begin{array}{c}4.0 \\
(4.9)\end{array}$ & $\begin{array}{c}1.0 \\
(1.9)\end{array}$ & $\begin{array}{c}3.9 \\
(0.9)\end{array}$ & $\begin{array}{l}\mathbf{5 6 . 7} \\
(0.9)\end{array}$ & $\begin{array}{c}5.0 \\
(0.6)\end{array}$ & $\begin{array}{l}12.9 \\
(4.1)\end{array}$ & $\begin{array}{l}15.8 \\
(1.2)\end{array}$ & $\begin{array}{l}11.2 \\
(4.6)\end{array}$ & $\begin{array}{c}3.4 \\
(2.0)\end{array}$ \\
\hline 8 & $\begin{array}{l}20.5 \\
(1.5)\end{array}$ & $\begin{array}{c}8.0 \\
(2.3)\end{array}$ & $\begin{array}{l}\mathbf{7 4 . 9} \\
(2.6)\end{array}$ & $\begin{array}{l}26.1 \\
(2.2)\end{array}$ & $\begin{array}{l}19.2 \\
(2.1)\end{array}$ & $\begin{array}{l}\mathbf{7 5 . 3} \\
(1.0)\end{array}$ & $\begin{array}{l}25.2 \\
(0.8)\end{array}$ & $\begin{array}{l}24.6 \\
(1.0)\end{array}$ & $\begin{array}{l}18.7 \\
(0.8)\end{array}$ & $\begin{array}{l}29.4 \\
(1.7)\end{array}$ & $\begin{array}{l}27.3 \\
(0.4)\end{array}$ \\
\hline
\end{tabular}

${ }^{\mathrm{a}} \mathrm{n}=3$, figures in brackets are relative standard deviation (RSD) values $(0.4-5.3 \%$ range)

Table 3: Extraction $^{\mathrm{a}}(\% \mathrm{E})$ of metal picrates with bis(spirolactam) calixarene hosts 12,13 and 14

\begin{tabular}{|c|c|c|c|c|c|c|}
\hline Host & $\mathbf{C o}^{2+}$ & $\mathbf{N i}^{2+}$ & $\mathbf{C u}^{2+}$ & $\mathbf{Z n}^{2+}$ & $\mathbf{C d}^{2+}$ & $\mathbf{P b}^{2+}$ \\
\hline $\mathbf{1 2}$ & 66.0 & 57.3 & 56.5 & 66.8 & 63.4 & 86.5 \\
\hline $\mathbf{1 3}$ & 62.5 & 64.5 & 47.3 & 50.5 & 50.4 & 64.8 \\
\hline $\mathbf{1 4}$ & 42.1 & 21.6 & 30.0 & 42.7 & 46.5 & 78.5 \\
\hline
\end{tabular}

${ }^{\mathrm{a}} \mathrm{n}=3$ (RSD values were $<5 \%$, in all cases) 